\title{
John Logie Baird and Television (Part 3)
}

\author{
By Gerald Pratley
}

Fall 1997 Issue of KINEMA

\section{MZTV: THE MUSEUM OF TELEVISION (Part 3 - Conclusion)}

In the large and lively offices and studios of CityTV, Much Music $\&$ Bravo! New style Arts Channel within the CHUM City building in downtown Toronto, three suites have been converted into a repository for television sets of all makes and models dating back to television's inception in the mid-1920s. This is the MZTV Museum of Television which has evolved from the personal collection of Moses Znaimer, the Canadian broadcaster and media innovator. The Museum is a non-profit entity without government funding and will eventually be open daily to the public. Presently, scholars, students, writers and others in the world of arts and entertainment may visit the museum by appointment.

The purpose of the Museum is to save and preserve the 70-year technological history of the TV receiver by spanning the evolution of television from the mechanical scanning discs of the 1920s to the solid-state electronics of the 1970s. By collecting, documenting and interpreting television sets and related ephemera, Znaimer's intention is to further public understanding of the impact and influence of a medium of communication which is powerful, persuasive and omnipresent. The Museum intends to be a live and living institution telling the story of television by involving the public in the MZTV oral history project in which people relate memories of early $T V$ and what it meant to them, what they have learned from it, and, among the younger generation, what television means to them in its present form. Electronic kiosks and computer websites are available at the Museum's exhibitions.

An historical and intriguing aspect of the MZTV Museum is the fact that its Collection Curator is Iain Baird, the 28-year-old grandson of John Logie Baird, a leader among the inventors of television. Baird's son, Malcolm Baird, a professor with the Department of Chemical Engineering at McMaster University, Hamilton, Ontario, contributed an essay on his father's work in Kinema No. 6 following Adrian Hills' consideration of him in Kinema No. 5, under the title "Eye of the world: John Logie Baird and Television Part 1" and "Eye of the world: John Logie Baird and Television Part 2". We are pleased to present Part 3 of Eye of the World in this conversation between Gerald Pratley and Iain Baird.

Mr. Baird, you just returned from one of the Museum's travelling exhibitions?

The MZTV Museum coordinates a travelling exhibition entitled "Watching TV: Historic Televisions and Memorabilia from the MZTV Museum" which explores the development of television as a medium. Sony, City interactive, CityTV, MusiquePlus and Bravo! have helped sponsor our first two exhibitions hosted by the Royal Ontario Museum (ROM) in Toronto, Ontario and at the Canadian Museum of Civilization (CMC) in Hull, Québec. This summer, the exhibition had a one month run at the Whyte Museum of the Canadian Rockies in Banff, Alberta. This coincided with the Banff Television Festival, attracting a very distinguished audience. The MZTV Museum has 250 historic television sets in its collection and 60 of the most significant examples form the core of this travelling exhibition "Watching TV".

The Museum has an excellent collection of mechanical televisions, very few of which have survived over the years without compatible broadcasts. There is the Jenkins model 202 Radiovisor, which needed a short-wave radio first to receive the signal, and then a moving shadow picture was reproduced on the unit. Television's origins were tied to radio in many ways, mainly because radio waves carried television signals which were received by a standard short-wave radio, which was then connected to a mechanical television. This Jenkins model is a 1929 48-line mechanical set using a scanning-drum instead of a disc to reproduce Jenkins' silhouette movies. These were shadow cartoons mostly, broadcast from transmitters in Washington and New York. Two lenses, 5-inch $(127 \mathrm{~mm})$ and 10-inch $(254 \mathrm{~mm})$, magnified the image. The Jenkins Television Corporation was founded in 1928 and offered various sets and kits for the radio-movie enthusiasts. At their peak, Jenkins claimed that 20,000 people were tuning in. 
The earliest television I have been able to document in the MZTV collection so far is the 1928 General Electric Octagon. Ernst Alexanderson was the Chief Consulting Engineer at General Electric laboratories in Schenectady, New York. He was the scientist who developed GE's first television system. The television has a 3-inch $(76 \mathrm{~mm})$ lens and although GE considered mass-production of it, they decided first to carry out experiments culminating in the elaborate transmission of the world's first television drama, The Queen's Messenger. Our set is one of at least four which survived and we believe that this particular one was used in the studio during the broadcast for the director to monitor the proceedings. There were three cameras in the studio, two were for shots of faces and the other for close ups like shots of hands and tea cups. The cameras had to be alternated at the right time, much like today, switching from camera one to camera two. The director was there in the studio watching the Octagon's 3-inch lens and gesturing the camera operators where to move during the play. This receiver is in very good condition, and is with the original accompanying Radiola 51 short wave receiver-amplifier. In general, the short wave receiver and disc were separate units connected by a cable, sometimes they were both built into the same cabinet.

We have two Baird televisors, one of which is in working condition, and have obtained some excellent 30-line pictures using a special reconstructed 30-line camera. The Baird televisor is significant because it is the first mass-produced widely available television set. It depends on how one defines mass production at that time in history, but in my opinion, the techniques used in the manufacture of the Plessey tin cabinet model made it more of a mass-produced item compared to the wooden models. These "tin stove" Baird televisors were the result of a collaboration between John Logie Baird and Percy Packman, an engineer at Plessey. Packman met Baird at the National Radio Exhibition in 1928 and witnessed the first line of Baird Televisors which had dark mahogany wooden cabinets with sloping tops. There were three 30-line models, A, B and C. The most expensive was the $\mathrm{C}$ model which had a large picture and a built-in sunburst speaker. The top model cost œ150, at that time a tremendous amount of money!

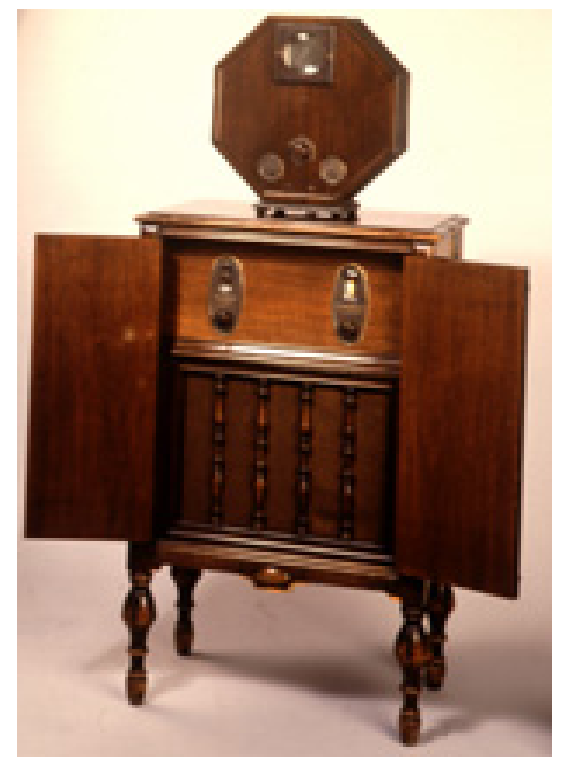

Figure 1: General Electric "Octagon"

My grandfather and Packman eventually worked out an arrangement where the Plessey company would build the "new" Baird televisors on contract on a large scale. The marketing of the new sets roughly coincided with the first regular television broadcasts on the BBC. Approximately one thousand of them were eventually sold, but the similar do-it-yourself kits proved to be much more popular, based on that design using the same 30-line system. The US seriously considered adopting Baird's television system from 1928 to 1931 , but decided otherwise because Baird television was a foreign company. In the UK, television broadcasts continued on the 30-line standard until 1935, then Baird began broadcasting with 240 lines. They were at this point during the competition with the Marconi-EMI's all-electronic 405 line system, and the Selsdon committee decided in favour of the Marconi system which became the BBC's broadcast standard until the 
$60 \mathrm{~s}$.

An early set of particular Canadian relevance is the Western scanning disc, having been used by a Montréal radio station, CKAC, in 1931; the first documented television broadcasts in Canada were broadcast from there. CKAC had the camera set-up also manufactured by Western, and used three 45-line Western scanning disc receivers.

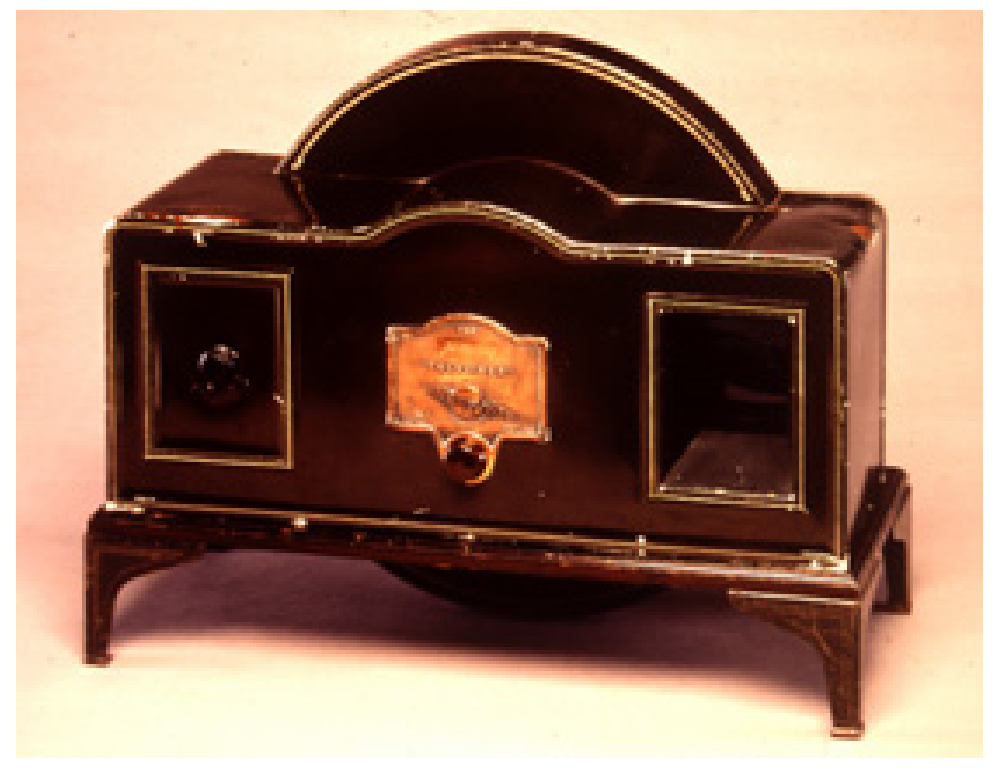

Figure 2: Baird Televisor

Well, we exhibited this television in the "Watching TV" exhibition in nearby Hull, Québec and I was hoping that an older visitor would come forward to say that they remember this, but no one did, unfortunately. Ironically, the 45-line Western system was replaced by an arm of Baird television in 1931 called Canadian Television Ltd. which used a 60-line system and a single lens-disc receiver. Douglas West was a Baird company engineer, and the leading figure trying to get Canadian Television Ltd. started. He also purchased some of Charles Francis Jenkins' television patents in a technology-sharing strategy to combine both Baird and Jenkins television systems for Canada. Sufficient capital to start mass- producing television receivers never materialize. Baird himself couldn't travel to Montréal because the cold winters would have seriously compromised his poor health. Alphonse Ouimet, a young engineer actually built the prototype receiver, and this was the start of his television career. Thirty years later he became President of the Canadian Broadcasting Corporation. So there is a definite link there and few people seem to know or remember that Canadian television was active close to the beginnings. Here at the MZTV Museum we are mainly concerned with North America's television history because countries or continents generally tend to have their own artifacts in museums.

When we move ahead a few years and look at the appearance of pre-war electronic televisions, the deluxe walnut cabinets and their design represented the future then having been carried over from the design of radios; you know, the 30s and 40s radios were often very deluxe items of furniture and those people who could afford to buy televisions wanted something in their living rooms that would match their Deco furniture. A good well-designed cabinet, with a means of hiding the screen, was important because television was only available for short periods. It was similar to the earliest days of radio when organized broadcasts were sporadic or only a few hours a day. In the early years of North American TV when it transmitted over the 441-line standard, programmes were only available for two or three hours a week so the large sets in particular had to look classy when they were switched off, or they would be considered an eyesore in the living room.

In the beginning of North American all-electronic TV, the leading manufacturer was the RCA Victor company. RCA was run by David Sarnoff at this time. It was Sarnoff that initiated the development of a television 
system proposed by a brilliant scientist hired from Westinghouse, Vladimir Zworykin. As part of this buildup, RCA bought up all TV patents outright and owned every television patent important to it. If there was a patent it couldn't buy it would have its research labs develop their way around the patent.

RCA came up against one major obstacle in the person of Philo T. Farnsworth who developed an allelectronic television system in 1927. Farnsworth held a patent for a camera pick-up tube known as the "Image Dissector". RCA couldn't get around all of the patents he filed and this delayed and put a different slant on North American television compared to the UK. In the United States, RCA also didn't feel that television was ready for the domestic market until they could combine the best features of the Image Dissector with RCA's Iconoscope tube, which Vladimir Zworykin first demonstrated in 1931. Farnsworth would only consider licensing his patents to RCA; finally, they agreed to this arrangement and went ahead. This legal wrangling delayed the release of television in the US until April of 1939, with RCA spearheading television broadcasting and receiver manufacturing.

In 1939, the first major display in Canada of all-electronic TV took place in a closed-circuit RCA demonstration at the Canadian National Exhibition in Toronto. But with the outbreak of WW II everything more or less came to a stop. In North America, we've come across virtually nothing television-related that was made between 1941 and 1946. There was experimentation going on in the US, but in terms of manufacturing and selling televisions it all ceased. Many of the pre-war sets that hadn't been sold by 1941 were stored in warehouses and not put on sale again until 1946.

\section{Do you feel that Farnsworth's and Baird's stories are similar?}

In many ways, yes, I think Farnsworth parallelled Baird's story. He was a clever inventor from Utah who was very inventive as a child. At 14, Farnsworth was thinking about scan lines as he was ploughing fields on his parents' farm. He was inspired by the radio and scientific magazines that he found in the attic. These made him think about electronics in general and possibly he may have read some of the work of A.A. Campbell Swinton, one of the earliest electronic television theorists. We are not sure what he read, but it would be exciting if the original magazines or a list of them ever turned up. They are part of the television history, but were probably thrown out as many valuable artifacts were. Anyway, he was developing this technology under a very low level of finance and he couldn't do much until George Everson and Leslie Gorell came in and financed his experiments, somewhat like Baird, who struggled with similarly meagre funds from William Day and General Electric. Farnsworth was able to develop a working system, but was constantly being asked "when are we going to see some dollar returns from this thing?" In one of his first demonstrations Farnsworth transmitted the dollar sign! Baird was in a similar situation. His financial supporters were always asking when they would see a return on their money. Eventually they did see it: on the TV screens. That was fair enough if you understood the development of television. Rewards always seemed very far away. At Alexandra Palace in 1936, Baird and Farnsworth both ended up working together in competition with what was essentially RCA's Iconoscope camera. I think both inventors followed parallel paths and many of the events of their later lives were sad.

Another of RCA's competitors at that time was Allan B. DuMont. He formed the television station WABD which competed with RCA's fledgling NBC. Using his 14-inch (355mm) cathode-ray-tube, his Model 180 television was released on to the market prior to RCA's first consumer set, the TRK-12. He was partially funded by Paramount Pictures -- Hollywood's first step into the camp of their future enemy.

It wasn't really until the late 1940s that televisions became commonplace, and receiver sales were beginning to take off. The first companies to manufacture modern television sets in Canada if I remember correctly were General Electric, Pye Canada, Brand and Millen, who distributed a Garod set, and of course, RCA. Many other companies followed, and for a while Canada had its own TV set manufacturing industry. Sony came on the scene in 1961 with its first set, the 8-301W, an example of which we have here in the collection, made in Japan, a miniature model with the entire front of the set being used for the screen which we identify with today, but at that time was revolutionary. The set won international design awards, and was considered to be very futuristic. Most portables were still using tubes, and were bulky and used too much power to be run from batteries. Portable TV sets were also encouraged by the popularity of transistor radios.

I think that what put it over the edge was Sony's introduction in 1969 of the Trinitron, a colour picture tube producing a brighter, sharper picture by using a single gun. Instead of three "dots" of colour making 
up each point on the screen, three bars of colour made up a point, the bars fit together better, and there is less unused space on the surface of the picture tube. The bars were not possible using the three-gun colour tubes that were in use at the time. Once Trinitron was developed, it gave us a picture much superior to anything else available. We have a very early model in the "Watching TV" exhibition, the first Trinitron television to be on sale in Canada in 1969, model KV-1200U. This set introduced the Trinitron to Canada, surpassing all competition at the time. An excellent machine, many of which are still in operation today.

J.L. Baird was actually developing a similar single-gun colour tube in 1946 as part of his extensive work into developing all-electronic high-definition three-dimensional colour television. RCA had also been working on a single-gun colour tube called the "Chromatron" in the 50s but abandoned it. Fortunately, Sony resumed research on the single-gun concept, and now most colour TV sets use it.

\section{How did this museum get started?}

Moses Znaimer is fascinated with the history of TV and its possibilities and implications. His appreciation of vintage receivers began with a "love at first sight" reaction to the design of a 1958 Philco Predicta which he saw while visiting Dr. Peter Goldmark at CBS Laboratories. He encountered surprising difficulty assembling a small collection of Philco Predictas, and became aware first-hand of the increasing scarcity of these important artifacts. The Museum began in earnest in 1992 as Moses began to purchase historic television sets from a variety of sources. These included two large existing major collections in the United States, and with other rare items still trickling in, the MZTV Museum now maintains the best collection in the world of North American televisions of historic importance. Moses made the decisions about what kind of museum he would have, what artifacts it would concentrate on -- would it be television receivers, ephemera and paper, broadcast equipment, video recorders? He decided to focus on objects related to television reception, as opposed to broadcasting in general. The programming side is well covered in a number of Canadian and American museums, and within the broadcasters' own private archives. At the moment, the collecting, preservation and restoration of historic television receivers in particular is the MZTV Museum's specialization. There have been a handful of vintage television collectors but I don't think anyone thought of opening an actual museum of television, with vintage television sets, open to the public. We are trying to retain the best that is Canadian and American.

How and when did you meet Moses Znaimer? Was he somewhat surprised and pleased at finding the grandson of the great inventor of the medium he loves so much actually living in Toronto-Hamilton and sharing a similar interest in collecting?

Well, I was at first interested only in collecting historic Canadian sets and I didn't know that anyone, certainly not Moses, whose television channels I grew up watching, held a similar interest. I knew that some television collecting was going on in the UK and the US but I thought that no one was doing this in Canada, and I felt that someone should be assembling some artifacts or the history would be lost. Soon I heard of Moses' intention of building a museum and made some enquiries about it. In my second year of collecting I ran into Gary Borton, who became the first Curator of the MZTV Museum. He told me that he was working for Moses Znaimer to establish a museum for historic television sets. Although I had then just finished studying heritage planning and urban history at the University of Toronto I thought I might try to turn my hobby of television history into a position here at MZTV. When the original curator decided to leave. I eventually worked up to curator because I had the same interest in the history of television, and I fit the bill as this subject matter is quite specialized.

I like to think that Moses appreciates the fact that J.L. Baird was my grandfather. Moses invited my father and me for a tour of the television stations. We met him over lunch and I think he found it appropriate that the descendants of the man who started it all should now be involved with a museum dedicated to television. The more people who get involved in this way, the better, as much of this history is yet to be recorded properly. The museum has tried to interview people who have direct memories of important television experiences. Living history is very important. For example, we received a very interesting letter from a Mrs. Johnston, now also living in Canada, whose father helped finance my grandfather's efforts in Cinema Television. Once Moses met an elderly lady during his travels in the States who was a dancer in some of the earliest TV transmissions from New York in 1931, and she provided us with documentation and a 1931 TV listing. Also, my father is a good friend of Donald Flamm, now aged 97, who met my grandfather in New York in 1931 and attempted to collaborate on TV transmissions in the US We try to follow up chance 


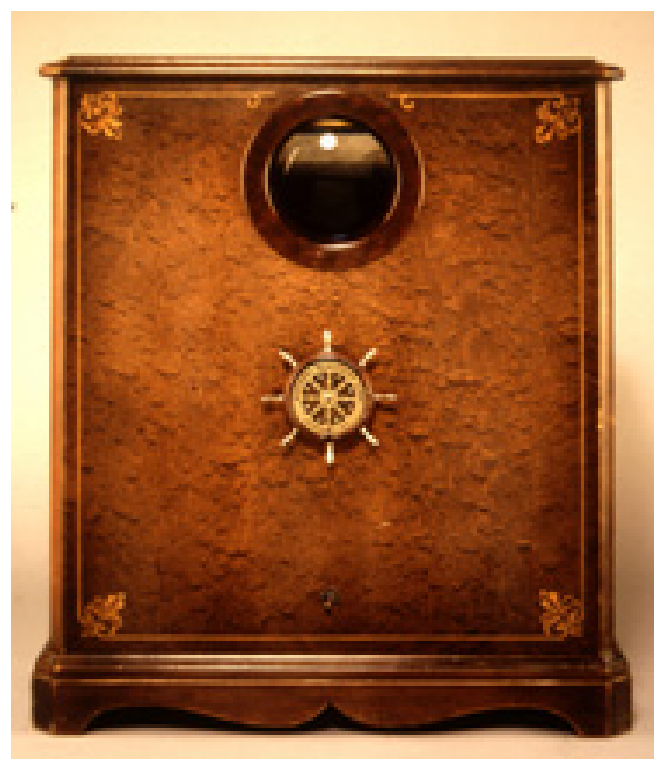

Figure 3: Western Electric "Visionette"

encounters with recorded interviews. MZTV, I believe, has become a part of TV history itself.

This museum got started very quickly. With most such enterprises it takes forever! There are countless meetings, endless discussions, arguments and changes of plans. It takes a lot of time to build them, get permissions, and to raise the money. Moses knew what he wanted and was in a position to create it without delay. The great advantage of the museum at this point in its development is that we have an excellent collection; we are meeting our goal of making it as accessible as possible. We have our catalogue, our travelling exhibitions and we've got a popular website as well. Museums are always trying to increase this kind of accessibility, because the less the artifacts travel physically, the better we can preserve them.

Response has been very positive from people attending the "Watching TV" exhibitions across Canada. The host museums appreciate having an exhibition relevant to the lives of people as living history in terms of what they can actually identify with in their own lives and activities. Everyone is an expert about television in their own way, and that makes our exhibition unique compared with the standard more traditional museum exhibitions. There are more opportunities for interactivity. The exhibition has an interactive section with the MZTV website accessible from computer terminals. The MZTV oral history project uses a Speakers' Corner unit, a talk-back booth, where visitors can recall their TV experiences while being recorded on video, and these are played back on monitors later during the run of the exhibition.

In the "Watching TV" exhibition travels so far, it has been set up in a roughly chronological way. In fact, the first thing you see when you enter is Felix the Cat. Felix was one of the first well-known North American television images. He was used as a test subject by RCA in 1928. As he revolved on the turntable for hours, he became North America's first TV Star. Unfortunately he fell off the turntable too many times, his head came off, and he was eventually replaced by a Mickey Mouse figure. We have the original Felix in the MZTV collection, the actual test subject used almost 70 years ago. His head is now attached with a wooden dowel. Moving on into the exhibition, visitors see the mechanical TV section, pre-war and immediate post-war electronic televisions. We have video modules devoted to the $50 \mathrm{~s}, 60 \mathrm{~s}$, and the $70 \mathrm{~s}$; other sections are divided into the story of the development of the medium, with contemporary video stations contrasting television as a vast wasteland; and as a vibrant medium of cultural expression. The short videos, produced by Reid Willis of the Media Television, cover key events in the history of television news, children's programs, music videos, "Fandom" (cult shows like Star Trek and Dr. Who), and nostalgic simulated living-rooms from the $50 \mathrm{~s}$ and the $70 \mathrm{~s}$ where one can watch vintage hockey or comedy shows. There are some extremely rare and interesting still images within the text panels. 
It must be difficult because television is such a vast subject, how can you come to grips with $i t$ ?

I think the subject matter we put into "Watching TV" so far is one approach, giving visitors an all-round and thought-provoking view of much that has happened so far and how the medium has grown. Television can also be divided up within a museum context, it is a technical story, it is a design story, it is a programming story, and the social impacts of television have certainly received the most attention and debate. Nonetheless, television is so ubiquitous in our lives that it remains very easy to take for granted, but it is that same ubiquity that makes it a challenge to interpret accurately. It is a vitally important cultural history to understand.

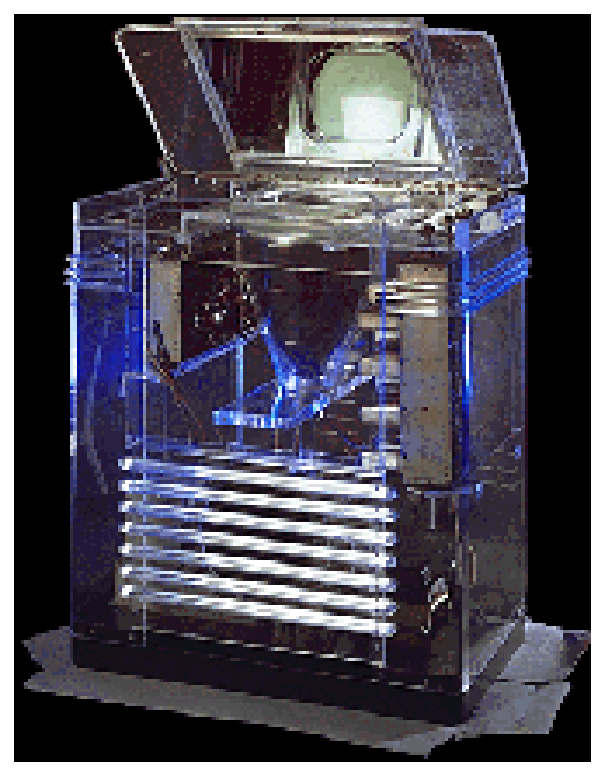

Figure 4: RCA Phantom Teleceiver. This specially constructed 1939 Lucite version of the production TRK12 television impressed visitors entering RCA's pavilion at the New York Word's Fair. The transparent cabinet, by industrial designer John Vassos, removed any doubt regarding the authenticity of the television images.

\section{Author Information}

Gerald PRATLEY, OC, LLD, started his career as film critic with the CBC. In 1969, he founded the Ontario Film Institute which he directed until 1990. He has written several books and numerous articles on film, including Torn Sprockets, a history of Canadian cinema. He taught Film History in universities in Toronto and Waterloo, Canada and holds three honorary degrees from Canadian and US universities.

Gerald A. Pratley (1923-2011) was born and educated in London, England, and came to Canada in 1946. He started working in Toronto for the $\mathrm{CBC}$ as a scriptwriter. He was drawn toward working in motion pictures, and became, in 1948, the CBC's first film critic and commentator.

Gerald Pratley broadcast three programmes a week, Pratley at the Movies, The Movie Scene, Music From the Films, and others, until 1975. During this time he also became the first post-war chairman of the Toronto Film Society, chairman of the Toronto and District Film Council and co-founder of the A-G-E Film Society and correspondent for international magazines such as Films and Filming, Film In Review, Variety, Hollywood Quarterly and International Film Guide. During the 1950s he wrote for Canadian Film Weekly and Canadian Film Digest.

He became known as a speaker on all aspects of motion picture art and industry, and was invited to teach film history at the University of Toronto, York University, University of Waterloo, Seneca College and Ryerson Polytechnical University, with individual lectures being given at many other Canadian and US universities 
and colleges. He has served as a member of various judging panels of competitions and festivals, being one of the members of the first Canadian Film Awards in 1949.

From 1970 to 1975 he was the director of the Stratford (Ontario) International Film Festival, and from 1969 to 1976 he was Chairman of the International Jury of the Canadian Film Awards. He has attended all the world's leading festivals of film, and in particular, for 30 years, the Cannes Festival as CBC correspondent. He has written six books, The Films of Frankenheimer: Forty Years in Film; The Cinema of John Frankenheimer; The Cinema of Otto Preminger; The Cinema of David Lean; The Cinema of John Huston, and Torn Sprockets, a history of the Canadian cinema.

Gerald Pratley has served on the Advisory Boards of the film departments of Ryerson Polytechnical University and Humber College, and as a member of the programme committee of TV Ontario. In 1968 he became the founder-director of the Ontario Film Institute of the Province of Ontario, an organization which has distinguished itself in archival holdings and public service and is known since 1990 as the Cinematheque of Ontario. He taught Film History courses at the Department of Film and Photography, Ryerson Polytechnic University, Toronto and the University of Waterloo.

In 1984, Gerald Pratley was made a Member of the Order of Canada and in 2003 Officer of the Order of Canada for his service to Canada through film appreciation. He holds Honorary Degrees in Letters and Fine Arts from York and Waterloo Universities (Ont., Canada) and Bowling Green State University (Ohio, USA).

In 2002, Gerald Pratley received a Special Genie Award from the Academy of Canadian Cinema \& Television in recognition of his lifelong dedication to the promotion and his exceptional support of Canadian cinema.

He died on 14 March 2011 in Ontario, Canada. 